\title{
Study on the Formation and Cultivation of Cultural Soft Power of Wuhan Shipping Center in the Middle Reaches of the Yangtze River
}

\author{
Xiaoliang Xiong \\ Wuhan Technology and Business University, Wuhan 430065, China \\ 345195568@qq.com
}

\begin{abstract}
Keywords: Middle reaches of the Yangtze River, shipping center, cultural soft power; cultural environment.
\end{abstract}

\begin{abstract}
Since the establishment of its position of national level shipping center, Wuhan Newport has not only been under the pressure of regional integration of Wuhan city circle and even of the whole province, but also has faced with the problems such as integration of resources, construction of port area and development of shipping service industry, etc., which is now at a critical juncture of functional transformation of urban shipping center and logistics center and of the enhancement of regional economic competitive advantages. At this point, the strategies such as promotion of the "practical" and "new" urban cultural dimensions, cultivation and building of shipping culture brand and quality products, establishment of cultural transmission system and external coordination system with new and hi-tech means and promotion of "stepping out" of culture, etc. are the important ways to cultivate and develop the cultural soft power of Wuhan shipping services.
\end{abstract}

\section{Introduction}

The government work report of the annual sessions of NPC and CPPCC in 2014 and the Guidance on Promotion of development of Yangtze River Economic Zone Based on the Golden Waterway issued by the State Council marked the establishment of Wuhan's position of national level shipping center, which not only put forward new strategic goal for the strategic conception of "Wuhan Shipping Center in the Middle Reaches of the Yangtze River" in 2004, but also set new and higher requirements for Wuhan Newport's functions as the urban shipping center and logistic center. Under the new situation that the shipping development mode speeding up its transformation and promoting effective competition, Wuhan Newport has its unique and tough task in terms of improving cultural soft power.

\section{Connotation of shipping culture resources and cultural soft power}

Shipping culture, the accompaniment of cities close to port, is a kind of cultural form and economic type. It is not only the outcome of the culture, but also the soul, the bone and the blood of the cities close to port. Without shipping culture and shipping industry, there would be no cities close to port and the city culture. The resource chain of shipping industrial structure and the capital chain of development soul as well as the content, production elements and knowledge elements of the shipping industrial culture and cultural industry always exist in the style system and style characteristics of the culture of cities close to port. As a relatively independent region of a country, and a relatively self-sufficient economic and social complexity, the city, no matter it is an old one or new one, oriental one or western one, inland one or coastal one, the main resources of its shipping cultural soft power would include the following aspects:

In the table above, the city spirit is not only the internal motivation for a city to develop, but also the inherent basis of the development pattern of a city, and for enhancing the shipping cultural soft power and strengthening the core competitiveness of the city. Therefore, it is a basic work of shipping cultural soft power to build a good city image. Shipping cultural facilities and organizations are the foundation for city to provide shipping public cultural services. The symbolic shipping cultural facilities have always been the important factors to the attractive and cohesive power of the city close to port. The 
international port city, especially the well-known city with strong shipping cultural soft power all have numerous shipping cultural, educational and scientific research institutions including many famous ones and has powerful strength in the respects of communication and information with no exception. Shipping culture brand is the representation of the productive competence of the culture of a city close to port. A good shipping cultural environment, such as the investment policies of shipping cultural undertakings, the talent cultivation policies of shipping culture, the encouragement policies of shipping cultural innovation (including literary and artistic creation and academic innovation), the land, capital, fiscal and taxation policies for the development of shipping cultural industry, the evaluation standard of shipping culture achievements and the quality system of shipping cultural products, etc. can effectively allocate social and cultural resources, mobilize the initiative of the talents of shipping culture and proactively promote the establishment and perfection of the shipping public cultural service system so as to promote and impel the development of shipping cultural industry[1].

Table 1 Constitution of shipping culture resources and cultural soft power

\begin{tabular}{|c|c|c|c|c|}
\hline \multirow[b]{2}{*}{$\begin{array}{l}\text { Culture of } \\
\text { the city } \\
\text { close to } \\
\text { port }\end{array}$} & City spirit & $\begin{array}{l}\text { The mainstream culture and dominant } \\
\text { values of the city close to port }\end{array}$ & $\begin{array}{c}\text { Core } \\
\text { components }\end{array}$ & \multirow{6}{*}{$\begin{array}{l}\text { Shipping } \\
\text { cultural } \\
\text { soft power }\end{array}$} \\
\hline & City image & $\begin{array}{l}\text { Outward images of the city's } \\
\text { architecture, outline, space and roads, } \\
\text { etc., and the inherent images of } \\
\text { government operation, social } \\
\text { management, development mode and } \\
\text { foreign policies, etc. }\end{array}$ & $\begin{array}{l}\text { Type } \\
\text { representation }\end{array}$ & \\
\hline \multirow{4}{*}{$\begin{array}{l}\text { Shipping } \\
\text { culture } \\
\text { resources }\end{array}$} & $\begin{array}{c}\text { Cultural } \\
\text { facilities and } \\
\text { organizations }\end{array}$ & $\begin{array}{l}\text { Shipping related museums, libraries, } \\
\text { universities and scientific research } \\
\text { institutions, etc. }\end{array}$ & $\begin{array}{l}\text { Hardware } \\
\text { component }\end{array}$ & \\
\hline & $\begin{array}{l}\text { Culture brand } \\
\text { and quality } \\
\text { production }\end{array}$ & $\begin{array}{l}\text { Activity brand and product brand of } \\
\text { shipping culture }\end{array}$ & $\begin{array}{c}\text { Key } \\
\text { component }\end{array}$ & \\
\hline & $\begin{array}{l}\text { Cultural } \\
\text { transmission } \\
\text { and information }\end{array}$ & $\begin{array}{l}\text { Broadcasting, television, newspapers } \\
\text { and periodicals, publish, network and } \\
\text { other communication means, etc. }\end{array}$ & $\begin{array}{l}\text { Important } \\
\text { component }\end{array}$ & \\
\hline & $\begin{array}{l}\text { Shipping } \\
\text { cultural } \\
\text { environment }\end{array}$ & $\begin{array}{l}\text { The policy environment such as the } \\
\text { policy, regulation and system, } \\
\text { mechanism of shipping culture } \\
\text { development, and the psychological } \\
\text { environment such as the social } \\
\text { psychology and values for the cultural } \\
\text { development }\end{array}$ & $\begin{array}{c}\text { Basic } \\
\text { condition }\end{array}$ & \\
\hline
\end{tabular}

\section{Construction of Wuhan shipping cultural soft power and shipping center}

Thanks to more than a hundred years of ups and downs in the urban development of Wuhan city and ten years' course of the construction of the shipping center, while we have obtained tremendous achievements in the economic and social development, a solid foundation has been laid for the shipping cultural soft power. In the questionnaire of "the sense of identity of Wuhan city by non-Wuhan native residents" of the research group, $64.24 \%$ of the interviewees held the view that Wuhan's historical and cultural background is attractive, $69.23 \%$ of them identified with the degree of internationalization of Wuhan metropolis and $71.79 \%$ of them identified with the capacity of Wuhan to be built as a national civilized city.

However, from the perspective of the cultural needs of city development and of the functions and missions that should be undertaken by the shipping center in the middle reaches of the Yangtze River, Wuhan's shipping cultural soft power is still insufficient. In the questionnaire of "the sense of identity 
of Wuhan city by non-Wuhan native residents" of the research group, only $34.87 \%$ of the interviewees consider that the cultural life in Wuhan is rich and the historical sites and modern architectures in Wuhan are simply overwhelming, only $16 \%$ of them said that they understand Wuhan's customs and only $43 \%$ of them expressed that they are satisfied with the scientific innovation degrees of Wuhan. Therefore, it is of great significance for the construction of Wuhan Shipping Center in the Middle Reaches of the Yangtze River to improve the shipping cultural soft power[2], which is mainly reflected in the following aspects: firstly, it is the inevitable choice of strengthening development sustainability. Since the implementation of reform and opening up for more than 30 years, Wuhan's economy has been maintained in a high-speed growth momentum of development with the port city value ranked the seventh nationwide. However, as time goes on, the port economic development of Wuhan is affected more and more obviously by the hard strength factors such as population, resources, land and environment, therefore, in order to maintain the future development potentials, we must do many things in the respects of system, mechanism, ideas and talents which are the basic issues involved in shipping cultural soft power. To resolve the problems in mechanism and in system, we must further emancipate our minds to establish new concepts and form new principles; secondly, the basic requirement of strengthening the comprehensive strength and competitiveness. Viewed in the process of the development trend of cities around the world, the interior driving force of the sustainable development of a city mainly lies in its culture. In 2014, Wuhan's cultural competitiveness ranked top seven in China, however, the contents included in such competitiveness mostly belong to something in ideology. In order to improve the shipping cultural soft power of Wuhan, we should make the shipping culture boom up and strongly develop the shipping cultural undertakings and cultural industry; thirdly, it is the important way to strengthen the cohesive and attractive power of Wuhan. When the city development has proceeded to a certain period, and the same economic and practical benefit is available in other cities, the main factor to attract outsiders depends on its culture [3]. Whereas, the formation of Wuhan shipping cultural soft power will produce cohesiveness internally and attractiveness externally, so as to strengthen the overall cultural identity and optimize the environment for talents accordingly; fourthly, it is the objective requirement to safeguard the citizen's cultural rights and interests. Wuhan is a metropolis with its population in urban area of more than 5 million, on the one hand, the citizens in Wuhan have huge cultural requirements, on the other hand, after the material wealth of the citizens in Wuhan reached a certain level, they will start to pursue rich and colorful cultural life and enjoy the cultural outcomes of various forms. To deeply exploit the shipping cultural resources and cultural value of our city and to create the diversified and multi-level shipping cultural products can further satisfy the spiritual and cultural needs of the masses.

\section{Ideas and suggestions on enhancing Wuhan shipping cultural soft power}

\subsection{Deeply promotion of the "practical" and "new" city cultural dimensions}

Wuhan, as the leading city rising in the central China, shall be at least has the following shipping culture dimensions to become the shipping center in the middle reaches of the Yangtze River: "practical", to construct the new "grand international wharf" development pattern with simplified customs clearance procedures and large-scale cooperation with broad cultural vision and magnanimous tolerant attitude and the cultural spirit of being realistic and pragmatic, "new", to perfect the smooth and unimpeded "three-dimensional grand wharf" with the cultural character of leading in the forefront and the active and flexible cultural mentality. More specifically, in terms of shipping mission, We shall inherit the Yangtze River civilization, and advocate the spirit of "practical, innovative, strengthening the port, and dedication" to provide the port and comprehensive logistics service of "safety, quality, high-efficiency and convenience" for powerful support of the regional economic development to improve the port value and city value in an all-round way. In terms of shipping concepts, we shall implement the scientific development concepts advocated by the sustainable development of the country and of the city and build the low-carbon logistics platform, low-carbon port by taking the environmental protection and resources conservation as the main line 
and the integrity in both government affairs and business affairs as the main body to serve the central China. Meanwhile, we should create the learning and innovative atmosphere to encourage the creation of excellent literary and artistic works related to low-carbon shipping to increase the public awareness of low-carbon shipping industry, strengthen the citizens' identity and sense of pride and improve the people's quality and the city image so as to construct a shipping center of the Yangtze River of "low-carbon, integrity, innovation and humanity". In terms of shipping values, we shall implement first-class services and first-class efficiency to become the trust-worthy comprehensive logistics service operation center.

\subsection{Concentrated on the cultivation and building of shipping cultural brands and quality products}

The more vividly the shipping cultural brands and the quality products are, the more abundant of the cultural connotation will be and the greater influence and promotion will be exerted to the self-development of the city close to port, thus the city close to port will have greater inspirational force and influence[4]. First of all, we should improve the supply capacity of cultural products and services to ensure the provision of diversified shipping cultural services and products to meet the cultural consumption demand of people from all walks of life and to promote the new growth point of city economic development. Secondly, we should build new shipping cultural brands and quality products according to the new changes in the cultural demand, including the festival activity of "Maritime Festival", shipping markers, museum and hero commemorative activities, etc. If the series of activities of "Shipping Culture Week of Wuhan Shipping Center" can be held, the last week of September every year as scheduled by the International Maritime Organization (IMO) or the "China National Maritime Day" every year as the first day can be referred as the specific holding time to mobilize the shipping related units, media and the social forces intensively throughout the city to display the achievements in Wuhan marine technology and the rich coastal resources of Wuhan to all sectors of the society vividly, promote Wuhan's shipping history of civilization and its contributions made for Chinese shipping industry, publicize the harmonious society and low carbon values and lead the citizens to understand and to participate in the shipping cultural activities with the influence and radiation of the brand to gradually form the characteristics advantages of Wuhan shipping culture.

\subsection{The cultural transmission system using new and hi-tech means}

The application of the modern technologies such as electronic publication, digital video and network transmission, etc. is the important part of the shipping cultural soft power of cities close to port. Making use of the advanced technical means can create rich and colorful information environment and provide more the better shipping cultural products and services media to display the high-end achievements of shipping culture, education and scientific research. The new media can be used to serve as the platform promoting the advanced shipping culture and providing advance shipping cultural services[5]. For example, we can adhere to the principle of combining the construction of major infrastructure with joint participation of the society in the construction of the shipping cultural symbol of the building of Wuhan Yangtze River Shipping Center and in the strategy of adding shipping streets and cultural facilities in the river beach from Jianghan Customs to the Second Yangtze River Bridge in Wuhan and in the idea of the functions of collection, research, exhibition and education of "Wuhan Transportation Museum". The network media platform is to be used as the important publicity base of Wuhan shipping culture, the academic research site of high-end shipping cultural, educational and scientific research talents and the Chinese and foreign cultural exchange platform as well as the shipping cultural activity promotion platform of the units such as the government departments, enterprises and associations of other provinces and cities, etc., thus to strengthen the expressiveness, attractiveness and influence of the traditional cultural activities to form the shipping cultural construction

\subsection{Establishment of the external coordinate mechanism and platform of "stepping out" of culture atmosphere for the whole society.}

The coordinate mechanism and platform environment of shipping culture are the basic conditions for the cultural soft power of cities close to port to develop. The construction of the platform of "stepping 
out" of Wuhan shipping culture shall give full play to the advantages of rich shipping cultural resources in Wuhan, and be used by the government to organize and coordinate the cultural exchange with foreign countries as well. For example, under the premise of progressive enhancement of Wuhan shipping cultural soft power and the gradually emerging of cultural effect, the cooperation in the aspects of the relative technical, talented personnel, capital and management of the cities with shipping centers in the middle reaches of the Yangtze River can be further deepened to realize the linkage development and integrative growth among the city ports. For example, the activities such as shipping related exhibitions, knowledge lectures, skills demonstration and competitions can be held over the same period in the related cultural venues of the various cities according to the different themes of "Shipping Culture Week" of every session; centrally organize the authoritative professional forum, convention and exhibition and Chinese and foreign exchange activities in other forms. At the same time, fully play the civil society groups and the intermediate organizations' role in Chinese and foreign exchanges to set up shipping cultural work promotion team in the association to centrally carry out the shipping cultural exchanges and activities for promoting friendship. The shipping related population entering into the schools or communities to provide publicity campaign, education and social public welfare services. The citizens and students are organized to visit and experience the practical activities in the shipping related cities and the concentrated promotion of excellent literary and artistic works and material products themed by the personnel or events related to shipping.

\section{Conclusion}

It has been presumed that shipping culture is not only the outcome of the culture, but also the soul, the bone and the blood of the cities close to port. Based on the analysis of construction of Wuhan shipping cultural soft power and shipping center, this paper proposes some strategies, such as deeply promotion of the "practical" and "new" city cultural dimensions, concentrated on the cultivation and building of shipping cultural brands and quality products, the cultural transmission system using new and hi-tech means, establishment of the external coordinate mechanism and platform of "stepping out" of culture atmosphere for the whole society.

\section{Acknowledgements}

This essay is the research results of national educational science the Twelfth Five-year Program held by the Ministry of Education. The theme of research is Museum Cultural Relics Resource Development and Application Research in Private-owned Schools (DIA150312).

\section{References}

[1] Pan Hongmin. Fresh water river valley is not always the eternal myth - An interview to Professor Liu Bin, director of world economy institute of Dalian Maritime University and doctoral supervisor [J]. World Shipping, 2014, (11): 1-3.

[2] Zhen Hong, Mao Boke, Jin Jiachen, Zhou Dequan. Formation and Development of International Shipping Center[M]. Shanghai: Shanghai Jiaotong University Press, 2012: 13-15.

[3] Shipping culture supports the shipping power [EB/OL]. Shipping Exchange Bulletin. Jincheng Logistics Network:http://info.jctrans.com/news/hyxw/2012111163353.shtml, 2012-1-1.

[4] Zhang Yanguo. Connotation, Nature and Characteristics of Yangtze River's Shipping Culture [N]. Guangming Daily, 2010, 4: 012 edition of Theory Weekly.

[5] Hu Yimin. Shipping Enterprise and Maritime Vocational Culture [M]. Dalian: Dalian Maritime University Press, 2012: 25-26. 